\title{
USP8/UBPy-regulated sorting and the development of sperm acrosome: the recruitment of MET
}

\author{
Giovanna Berruti and Chiara Paiardi \\ Department of Biosciences, University of Milan, via Celoria 26, 20133 Milan, Italy \\ Correspondence should be addressed to G Berruti; Email: giovanna.berruti@unimi.it
}

\begin{abstract}
The acrosome is a peculiar vacuole that at fertilization undergoes the acrosome reaction (AR), an event unique in the sperm life. Contents released promote sperm penetration through oocyte's investments; membranous components are involved in sperm-egg interaction/fusion. Therefore, both constituents play a role in fertilization. The biogenesis of this vacuole, however, has not been clarified yet; recently, it has been proposed as a novel lysosome-related organelle (LRO). Our research focuses on the involvement of the endosomal pathway in acrosomogenesis starting from the early phases. The trafficking sorted by USP8/UBPy, an endosomal regulator recently described as a compelling candidate for male fertility gene, was investigated in comparison to that of SP56, a marker of the biosynthetic pathway. Mouse spermatids were double/triple immunolabeled and examined by confocal microscopy. The contribution of the vesicular traffic assisted by the cortical microtubule array was also evaluated in nocodazole-treated spermatids. USP8/UBPy-sorted cargo contributes early to acrosomogenesis and its trafficking is microtubule mediated. It was identified, through co-immunoprecipitation/co-immunolocalization assays, that the membrane receptor MET, described herein for the first time in spermatids, as an USP8/UBPy-target substrate is delivered to the acrosome. MET and USP8/UBPy still colocalize in epididymal spermatozoa. Following the AR, MET and USP8/UBPy show a distinct fate. MET, in particular, translocates at the PAS, the post acrosomal segment known to harbor sperm-borne factors involved in oocyte activation. Overall, our results support the concept of the acrosome as a LRO and provide evidence for the identification of MET as a tyrosine kinase receptor that may play a role in fertilization.

Reproduction (2015) 149 633-644
\end{abstract}

\section{Introduction}

The acrosome is a unique membranous organelle located over the anterior part of the sperm nucleus that is essential for normal fertilization because spermatozoa lacking these structures are infertile (Holstein et al. 1973). To penetrate into the oocyte's investments and to fertilize the oocyte, the spermatozoon must undergo a dramatic morphological change known as the acrosome reaction (AR; Yanagimachi 2011). At the triggering of the $A R$, the outer acrosomal membrane (OAM) fuses with the overlying plasma membrane and both are lost as hybrid vesicles, thus allowing the release of the soluble acrosomal content to open the sperm's passage. The luminal content also includes a particulate material, the acrosomal matrix, that provides a stable scaffold for interactions between the sperm and oocyte (Lin et al. 2007, Guyonnet et al. 2012). The inner acrosomal membrane (IAM), on its own, does not vesiculate, but remains intact as a cap to protect the underlying nuclear envelope. With the restructuring of sperm membranes in order to promote the exposure of the sperm fusion factor(s) and the internalization of the invaginated acrosomal membrane that encapsulates the paternal genome, fertilization is then fully accomplished (Satouh et al. 2012). Each acrosomal component is consequently crucial for successful fertilization; this functional importance is strengthened by the fact that they are conserved in spermatozoa across mammalian species including human. Notwithstanding this, the precise mechanism through which the acrosome develops and forms is not fully known as yet. Traditionally, acrosomogenesis is subdivided into four sequential phases that cumulatively last long about 2 weeks in the mouse and 1 month in the human (Lin et al. 2007). The basic premise to fulfill the entire process is that defined protein cargoes have to be recognized and delivered to the appropriate acrosomal compartment; this could occur with the aid of selected effectors of vesicular traffic, including both sorting/ tethering factors and motor protein-assisted cytoskeletal tracks (Berruti \& Paiardi 2011). The biosynthetic pathway through the Golgi apparatus is actively involved (Tang et al. 1982, Fujihara et al. 2012), but contribution of extra-Golgi pathways has also been documented (Berruti \& Paiardi 2011). The finding that the endosomal-sorting complex required for transport (ESCRT)-deubiquitinating (DUB) enzyme USP8/UBPy is involved in the acrosome biogenesis (Berruti \& Martegani 2005, Berruti et al. 
2010) has led to the proposal of the acrosome as a novel lysosome-related-organelle (LRO) (Berruti et al. 2010). LROs are cell type-specific membrane-bound organelles that arise by cargo delivery from early endosomal intermediates, the organelles that connect the endocytic and biosynthetic pathways (Huizing et al. 2008, Delevoye et al. 2009). In support of the acrosome as an LRO, there are recent proteomic studies providing the overlap between the profiling of LRO (Hu et al. 2007) and acrosomal matrix (Guyonnet et al. 2012) proteomes. USP8/UBPy is a key regulator of protein sorting at the endocytic route; in particular, it controls the dynamics and fate of membrane growth factor receptors by regulating the level of their ubiquitination on endosomes (Mizuno et al. 2006, Row et al. 2006, Niendorf et al. 2007, Wright et al. 2011, Berruti \& Martegani 2013). Among the first receptors reported to be the target of USP8/UBPy, there is the membrane tyrosine kinase, MET, also known as the hepatocyte growth factor (HGF) receptor (Row et al. 2006). MET signaling regulates crucial biological activities such as cell proliferation, morphogenesis, motogenesis and invasion in the embryo as well as in the adult (Birchmeier et al. 2003, Trusolino et al. 2010, Woodard et al. 2013). HGF/MET system is expressed also in the testis (Ricci \& Catizone 2014).

In this study, we have defined the contribution of USP8/UBPy to the acrosome biogenesis in a better way, demonstrating the early involvement, microtubulemediated, of the endosomal pathway. Moreover, we have identified MET, described herein for the first time in post-meiotic spermatids, as an USP8/UBPy-sorted molecular target recruited to the acrosome. In epididymal spermatozoa, MET and USP8/UBPy still colocalize. With the induction of the AR, MET relocates to a sperm region, the post-acrosomal segment (PAS), known to harbor sperm-borne factors involved in oocyte activation.

\section{Materials and methods}

\section{Animals}

Testes and epididymides were isolated from CD1 male mice purchased from Charles River Italia (Calco, Lecco, Italy). The animals were housed at the standard conditions (temperature of $21 \pm 1{ }^{\circ} \mathrm{C}$ with relative humidity of $55 \pm 10 \%$ and $12 \mathrm{~h}$ light: $12 \mathrm{~h}$ darkness cycle) and killed by $\mathrm{CO}_{2}$ asphyxiation at the selected time-points. All efforts were made to minimize the number of animals used in this study as organ donors.

All procedures were carried out in accordance with the National and European directives for the care and use of laboratory animals (D.L. 116/1992; 86/609/CEE) and the NIH Guide for the Care and Use of Laboratory Animals. Animal protocols were reviewed and approved by the ethical committee for animal experimentation of the University of Milan and by the Italian Ministry of Health.

\section{Antibodies}

Primary antibodies used are as follows: rabbit anti-mUBPy/USP8 was prepared as described previously (Gnesutta et al. 2001); rabbit polyclonal anti-MET (SP260, sc-162) with its blocking peptide sc-162 $\mathrm{P}$ and mouse monoclonal anti-MET (B-2, sc-8057) with its blocking peptide sc-8057 P were purchased from Santa Cruz Biotechnology; mouse monoclonal anti-SP56 antibody (clone 7C5, MA1-10866) was obtained from Thermo Fisher Scientific, Inc. (Rockford, IL, USA); mouse monoclonal anti- $\beta$-tubulin (clone TUB 2.1, T4026) was purchased from Sigma-Aldrich Chemical Company and sheep polyclonal anti-tubulin (ATN02) was obtained from Cytoskeleton (Denver, CO, USA).

Secondary antibodies used for immunofluorescence (goat anti-rabbit IgG Alexa Fluor 488 and Alexa Fluor 568, goat antimouse IgG Alexa Fluor 488 and Alexa Fluor 568 and donkey anti-sheep IgG Alexa Fluor 488) were purchased from Invitrogen. HRP-coupled anti-rabbit and anti-mouse secondary antibodies were obtained from GE Healthcare (Buckinghamshire, UK).

\section{Isolation of spermatogenic cells, sperm collection and cell counts}

Spermatogenic cells were isolated from testis in RPMI-1640 medium (Sigma-Aldrich Chemical Company) by sequential enzymatic treatments according to well-standardized protocols (Berruti \& Martegani 2005, Aivatiadou et al. 2009, Berruti et al. 2010). For sperm collection, epididymes were dissected, cut in to small pieces and the sperm were allowed to swim out in calciumfree motility buffer for $30 \mathrm{~min}$ as described previously (Paiardi et al. 2011). The numbers of cells were determined by hemocytometer counts either undiluted or diluted tenfold. All counts were made in duplicate and averaged (Berruti \& Martegani 2005, Aivatiadou et al. 2009). Cell viability was assessed by the Trypan blue exclusion test (Aivatiadou et al. 2009).

\section{Nocodazole treatment}

Freshly isolated spermatogenic cells were cultured in Falcon petri dishes in RPMI-1640 medium supplemented with $25 \mathrm{mM}$ HEPES, 0.5\% BSA (Sigma-Aldrich Chemical Company), $100 \mu \mathrm{g} / \mathrm{ml}$ streptomycin and $100 \mu \mathrm{g} / \mathrm{ml}$ penicillin (Euroclone Life Sciences, Milano, Italy) at a density of $1-3 \times 10^{6}$ cells $/ \mathrm{ml}$. Nocodazole (Sigma-Aldrich Chemical Company) was added to the cell culture until a final concentration of $5 \mu \mathrm{M}$ was achieved. Cells were incubated with either nocodazole or vehicle only (DMSO) for $1 \mathrm{~h}$ in a $5 \% \mathrm{CO}_{2}$ incubator at $33{ }^{\circ} \mathrm{C}$. The cells were collected by centrifugation and washed twice in RPMI to remove nocodazole before being processed for paraformaldehyde fixation.

\section{Protein extracts and western blotting}

One-percent Triton X-100 protein lysates were obtained as described (Berruti \& Martegani 2005, Aivatiadou et al. 2009). Alternatively, freshly isolated spermatogenic and sperm cells were lysed in RIPA buffer (50 mM HEPES, pH 7.5, 150 mM 
$\mathrm{NaCl}, 0.5 \%$ NP-40, $0.1 \%$ SDS, $0.5 \%$ deoxycholate, $1 \mathrm{mM}$ EDTA, $30 \mathrm{mM} \mathrm{NaF}, 1 \mathrm{mM} \mathrm{Na} \mathrm{VO}_{4}, 1 \mathrm{mM}$ phenylmethylsulphonyl fluoride (PMSF) and Complete Mini Protease Inhibitor Cocktail) for $15 \mathrm{~min}$ at $4{ }^{\circ} \mathrm{C}$ under gentle shaking. Occasionally, some samples were subjected to sonication (Berruti \& Martegani 2005). Lysates were clarified by centrifugation at $15700 \mathrm{~g}$ for $10 \mathrm{~min}$ at $4{ }^{\circ} \mathrm{C}$ and supernatants recovered. For testis and liver homogenates, the tissues were mechanically homogenized in RIPA buffer and then processed as described earlier in this study.

Protein concentration was determined using a standard protein assay (Bio-Rad DC, Bio-Rad). Protein extracts were resolved on SDS-PAGE and transferred onto a nitrocellulose membrane (Hybond-ECL, GE Healthcare). Western blotting using a chemiluminescence detection system (LiteABlot Plus, Euroclone Life Sciences) was performed essentially as described previously (Aivatiadou et al. 2009, Berruti et al. 2010). To saturate anti-MET antibodies, the antibodies were combined with a sevenfold (by weight) excess of the blocking peptides according to the manufacturer's instructions (Santa Cruz Biotechology).

\section{Co-immunoprecipitations}

Freshly isolated spermatogenic cells were divided into two aliquots; an aliquot was directly solubilized with lysis buffer (50 mM HEPES, pH 7.4, $100 \mathrm{mM} \mathrm{NaCl}, 0.5 \% \mathrm{NP}-40 \mathrm{w} / \mathrm{v}, 1 \mathrm{mM}$ EDTA, $50 \mathrm{mM} \mathrm{NaF}, 1 \mathrm{mM} \mathrm{Na} \mathrm{VO}_{4}, 1 \mathrm{mM}$ PMSF and Complete Mini Protease Inhibitor Cocktail) for $40 \mathrm{~min}$ at $4{ }^{\circ} \mathrm{C}$ under gentle shaking. To analyze protein association in HGF-stimulated cells, cells of the remnant aliquot were resuspended in the supplemented RPMI-1640 medium at a density of $1-2 \times 10^{6}$ cells $/ \mathrm{ml}$ and incubated as described (Aivatiadou et al. 2009). Then, cells were stimulated with $50 \mathrm{ng} / \mathrm{ml} \mathrm{HGF}$ (recombinant murine HGF, PeproTech, Tebu-Bio, Magenta, Italy) for another $30 \mathrm{~min}$ at $33{ }^{\circ} \mathrm{C}$ in a $5 \% \mathrm{CO}_{2}$ incubator. Cells were washed with cold PBS, collected by centrifugation and resuspended in lysis buffer to be processed as described earlier in this study for un-stimulated cells. The lysates were clarified by centrifugation $\left(10000 \mathrm{~g}, 10 \mathrm{~min}, 4{ }^{\circ} \mathrm{C}\right.$ ) and the protein concentration was determined. Clarified lysates were used directly for immunoblotting or processed for immunoprecipitation. Equivalent $(650 \mu \mathrm{g})$ aliquots of protein lysates were incubated with antiUBPy/USP8 or preimmune rabbit serum and processed as described previously (Berruti et al. 2010). After extensive washings (four times in $50 \mathrm{mM}$ Tris- $\mathrm{HCl}, \mathrm{pH} 7.4,100 \mathrm{mM}$ $\mathrm{NaCl}$ and $1 \mathrm{mM}$ EDTA), the immunocomplexes were eluted by boiling in $2 \times$ SDS sample buffer and then resolved by SDSPAGE. Immunoblotting of protein lysates and immunocomplexes was performed with the appropriate primary antibody.

\section{Acrosome reaction}

Epididymal sperm were obtained by 'swim-out' from snipped caudae kept in HEPES-buffered Whitten medium without BSA as described (Sosnik et al. 2010). Following a rinsing, sperm were resuspended in the modified Whitten medium at a concentration of $2-3 \times 10^{6}$ cells $/ \mathrm{ml}$ and herein maintained at $37^{\circ} \mathrm{C}$ for $1 \mathrm{~h}$. The AR was then induced with $10 \mu \mathrm{M}$ calcium ionophore A23187 (Sigma-Aldrich) and $2.4 \mathrm{mM} \mathrm{CaCl}$. Equivalent aliquots of sperm suspension were removed at 0, 5, 15 and 30 min from A23187 addition, washed in tris buffered saline (TBS), smeared on glass slides and allowed to adhere at room temperature to be processed afterwards for immunocytochemistry. Parallel aliquots of sperm suspension at the same time-points were processed for Coomassie Brilliant blue (Sigma-Aldrich) staining technique (Feng et al. 1998) to assess the progression of the AR. At least 200 glass slidesmeared sperm/time-points were scored using an Axiovert $200 \mathrm{M}$ inverted microscope equipped with bright-field light optics. The percentage of acrosome-reacted (no blue acrosome staining) sperm vs acrosome-intact (blue acrosome cap) sperm at each of the above time-points was calculated and the results are expressed as mean \pm S.E.M.

\section{Immunocytochemistry}

Freshly isolated and nocodazole-treated spermatogenic cells were processed for indirect immunofluorescence as described (Berruti et al. 2010). Briefly, 4\% (v/v) paraformaldehyde-fixed, ice-cold acetone-postfixed, preblocked spermatogenic cells were immunostained with the indicated primary antibodies, that is, anti-UBPy/USP8 (1:300), anti-SP56 (1:250), anti- $\beta$ / $\alpha$-tubulin (1:300) and anti-MET (1:50) followed by the appropriate Alexa Fluor 488- or Alexa Fluor 568-conjugated secondary antibodies. Nuclei counterstaining was carried out with 4',6-diamidino-2-phenylindole (DAPI; $2 \mu \mathrm{g} / \mathrm{ml}$, SigmaAldrich Chemical Company) or with Draq5 (5 $\mu \mathrm{M}$, Biostatus Limited, Shepshed, UK).

In control samples, the primary antibodies were omitted or, in the case of MET, replaced with primary antibody neutralized with blocking peptide according to the manufacturing procedures.

Epididymal sperm cells were fixed in ice-cold methanol for $10 \mathrm{~min}$, post-fixed in ice-cold acetone for $5 \mathrm{~s}$ and processed for immunostaining as described earlier in this study. For spermatogenic cells isolated without enzymatic treatment, fragmented material was prepared essentially according to Guttman et al. (2004). Decapsulated testes/seminiferous tubules were minced into small pieces in RPMI-1640 medium. The pieces were fixed in $4 \%(\mathrm{v} / \mathrm{v})$ paraformaldehyde for $2 \mathrm{~h}$ at $4{ }^{\circ} \mathrm{C}$ and then transferred into a tube containing $\sim 5 \mathrm{ml}$ of TBS. The material was gently passed first through an 18-gauge and then through a 21-gauge needle for five times per each. The larger fragmented material was left to sediment by gravity at room temperature for $5 \mathrm{~min}$; the upper layer was thus transferred to another tube for centrifugation. The pellet was resuspended into a small volume of TBS and the suspension was smeared onto slides and allowed to adhere. The slides were post-fixed with ice-cold acetone for $5 \mathrm{~min}$, rinsed in TBS and, after the blocking step, processed for immunofluorescence as described earlier in this study.

\section{Immunohistochemistry}

For traditional immunohistochemistry, testes were fixed in Bouin's fixative at $4{ }^{\circ} \mathrm{C}$ overnight, embedded in paraffin wax and sectioned at a thickness of $6 \mu \mathrm{m}$ (Paiardi et al. 2011). 
A

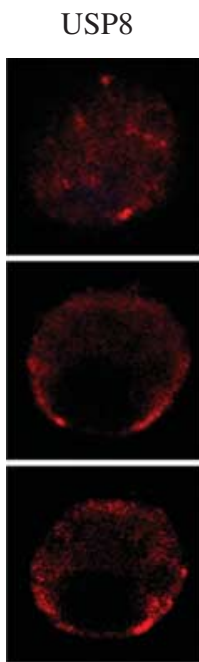

$\mathrm{A}^{\prime}$

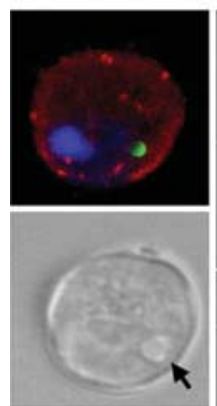

SP56
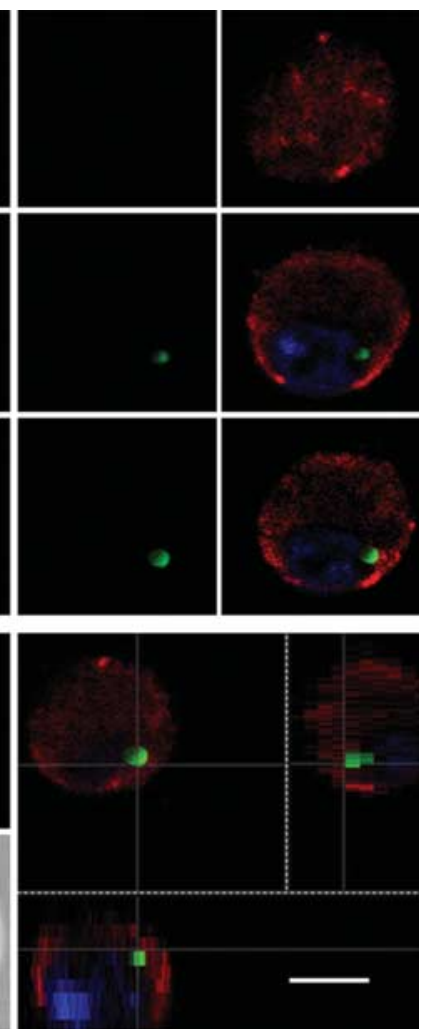

B
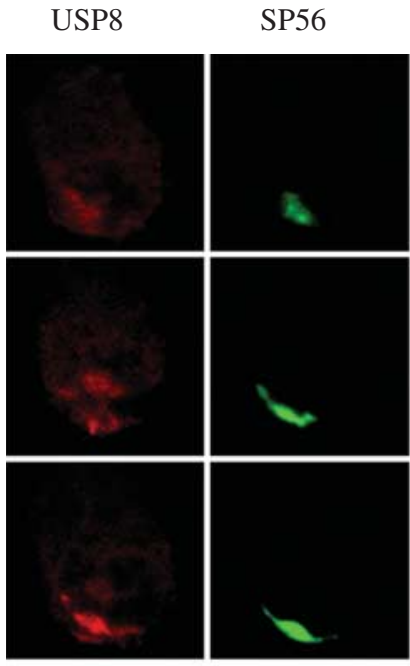

$\mathrm{B}^{\prime}$
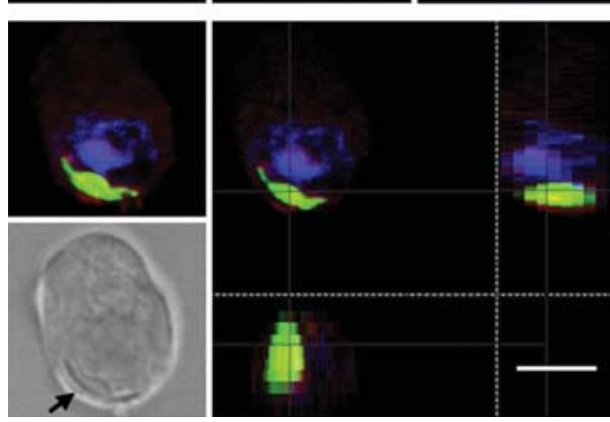

\section{Merge}
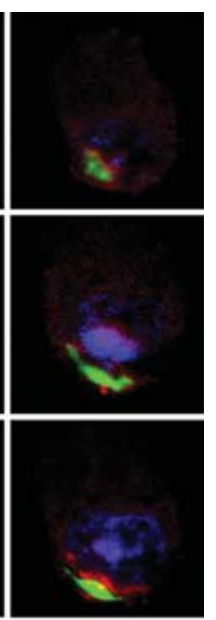

Reproduction (2015) 149 633-644
Deparaffinized sections, after blocking with 3\% BSA for 45 min and with $3 \% \mathrm{BSA}+0.1 \%$ Triton $\mathrm{X}-100$ for $15 \mathrm{~min}$, were incubated with anti-MET antibodies (1:50), followed by an Alexa-conjugated secondary antibody. Nuclei counterstaining was carried out with $2 \mu \mathrm{g} / \mathrm{ml}$ DAPI. Seminiferous tubules fixed in $4 \%(\mathrm{v} / \mathrm{v})$ paraformaldehyde to be used for surface antigen detection were incubated with an anti-MET antibody essentially as described by Catizone et al. (2012). Immunostained tubules were then mounted onto slides, covered with coverslips and squashed to allow cell to flow out. Controls were with the MET primary antibody neutralized with its blocking peptide.

\section{Microscopy}

For simultaneous double immunolabeling, cells were examined under a Leica TCS SPAOBS scanning laser confocal fluorescent microscope (Leica Lasertecknik $\mathrm{GmbH}$, Heidelberg, Germany) equipped with laser $\mathrm{Ar} / \mathrm{Kr}$ (488 nm), laser $\mathrm{He} / \mathrm{Ne}(568 \mathrm{~nm})$ and laser u.v. (361-365 nm) for green, red and blue fluorescence respectively. Images were captured under $63 \times$ magnification using identical laser power, light pathways and band passes by a computerized system (Leica Power Scan Software, Heidelberg, Germany). Captured images were elaborated with Adobe Photoshop. For single immunofluorescence analysis, the samples were analyzed under an Axiovert $200 \mathrm{M}$ inverted microscope (Zeiss Microscopy $\mathrm{GmbH}$, Jena, Germany), equipped with standard filter sets for green (Alexa Fluor 488), red (Alexa Fluor 568) and blue (DAPI) fluorescence and a Zeiss AxioCam, CCD camera. Acquired images were elaborated with Adobe Photoshop.

\section{Results}

\section{Endocytic vs biosynthetic route in acrosome biogenesis}

To understand the possible origin of components of the acrosome, we carried out an extensive immunofluorescence analysis to determine first, by reciprocal comparison, the cellular localization of USP8/UBPy and SP56, a protein of the acrosomal matrix used as a marker of the biosynthetic pathway (Kim et al. 2001). Doublefluorescent protein immunostaining was matched with DAPI to visualize nuclear spermatid morphology during the distinct phases of acrosomogenesis. Representative images are provided in Fig. 1. At the Golgi phase,

Figure 1 USP8/UBPy and SP56 do not colocalize at the early acrosomogenic phases. Confocal microscopy was performed on spermatids at the Golgi phase (A) and cap phase (B) after immunostaining against USP8/UBPy and SP56 and counterstaining with DAPI. Images at each strips in both A and B represent a single slice captured starting from cell periphery toward a deeper cell localization. Triple-color overlays are shown at the right. $\mathrm{A}^{\prime}$ and $\mathrm{B}^{\prime}$ show: top left, the sum of the optical sections of $A$ and $B$ respectively; bottom left, the light transmission image where it is possible to appreciate the proacrosomal granule and acrosomal cap respectively (arrow); right, the orthogonal projections on $Z$ axis (scanned along $Z$ axis). Results are representative of at least eight cells at the specified differentiation step in three different, separate experiments. Bar $=8 \mu \mathrm{m}$. 
characterized by the fusion of Golgi-derived proacrosomal granules with a single acrosomal granule that then attaches to the cell nucleus, SP56 was detected only within the developing acrosomal granule next to contact the nuclear envelope (Fig. 1A). On the contrary, USP8/ UBPy exhibited a diffuse localization marked, especially at the cell periphery, by scattered fair spots ascribable to vesicular structures (Fig. 1A). No USP8/UBPy-SP56 overlapping was ever detected at any focal plane in Golgi-phase spermatids as indicated also by the $Z$-axis stacks (Fig. $1 \mathrm{~A}$ and $\mathrm{A}^{\prime}$ ). During the cap phase, fusion of further vesicles around the granule leads to the formation of the acrosomal vesicle. Triple-fluorescent labeling showed that, in cap-phase spermatids (Fig. 1B), both USP8/UBPy and SP56 are resident at the acrosomal vesicle. Superimposition of the respective images examined at more focal planes, however, revealed that while SP56 marks the acrosomal matrix as expected, USP8/UBPy signs predominantly the profile of the vesicle lining the OAM and IAM, oriented toward the cell surface and acroplaxoma-nucleus respectively. Accordingly, no significant USP8/UBPy-SP56 overlapping was yielded also by the Z-axis stacks (Fig. 1B and $B^{\prime}$ ). It follows that at least two pathways of vesicle trafficking contribute molecules to the developing acrosome in round spermatids.

The successive phases are characterized by morphological/structural changes. The acrosome phase is signed by nucleus/acrosome elongation while at the maturation phase the acrosome acquires its final shape; at spermiation, mature spermatids are released as spermatozoa within the tubule lumen. Figure 2 shows USP8/ UBPy and SP56 relationship in germ cells at these developmental stages. Notwithstanding the structural remodeling of the spermatid head in progress, USP8/ UBPy and SP56 still maintain distinct distribution. At the acrosomal phase (Fig. 2A), USP8/UBPy marks gradually the shaping of the acrosomal vesicle now embracing the apical one-third of the nucleus; on the other hand, SP56 remains luminally confined to the central portion of the acrosomal matrix. This occurs also successively when the acrosome has acquired its typical hook-like shape and spermatozoa are then released (Fig. 2B and C). Superimposition of the immunofluorescence images (Fig. 2) did not result in any significant protein overlapping also considering the consistent thinning of the sperm acrosome.

\section{The microtubule array and acrosomogenesis}

Acrosome biogenesis is a microtubule-mediated event (Moreno et al. 2006). Spermatids at the early (Golgi and cap) phases of acrosomogenesis exhibit a rather unusual microtubule array, i.e., a cortical network without any apparent nucleating foci and with undistinguishable plus- and minus-ends; however, some microtubules penetrate deep into the cytoplasm. Another spermatid peculiarity is the spatial orientation and fate of the Golgi complex. As a consequence of the Golgi rotation during early spermiogenesis, the cis-Golgi and trans-Golginetwork (TGN) locate toward the cell surface and the developing acrosome/nucleus respectively (Griffiths et al. 1994, Moreno et al. 2006). We double-stained, USP8/UBPy-tubulin and SP56/tubulin, respectively, mouse spermatids that were then examined by confocal microscopy. During the Golgi phase, there were detected USP8/UBPy-labeled vesicular structures in close contact with the cortical microtubule network (Fig. 3A, left). Indeed, USP8/UBPy possesses an microtubule interacting and transport (MIT) domain through which it could bind to microtubules (Row et al. 2007, Berruti et al. 2010). SP56, on its own, stained the proacrosomal granule that is more deeply located; no apparent SP56/microtubule array overlapping was revealed (Fig. 3B, left). The cortical microtubule array starts to disassemble at the cap phase when USP8/UBPy

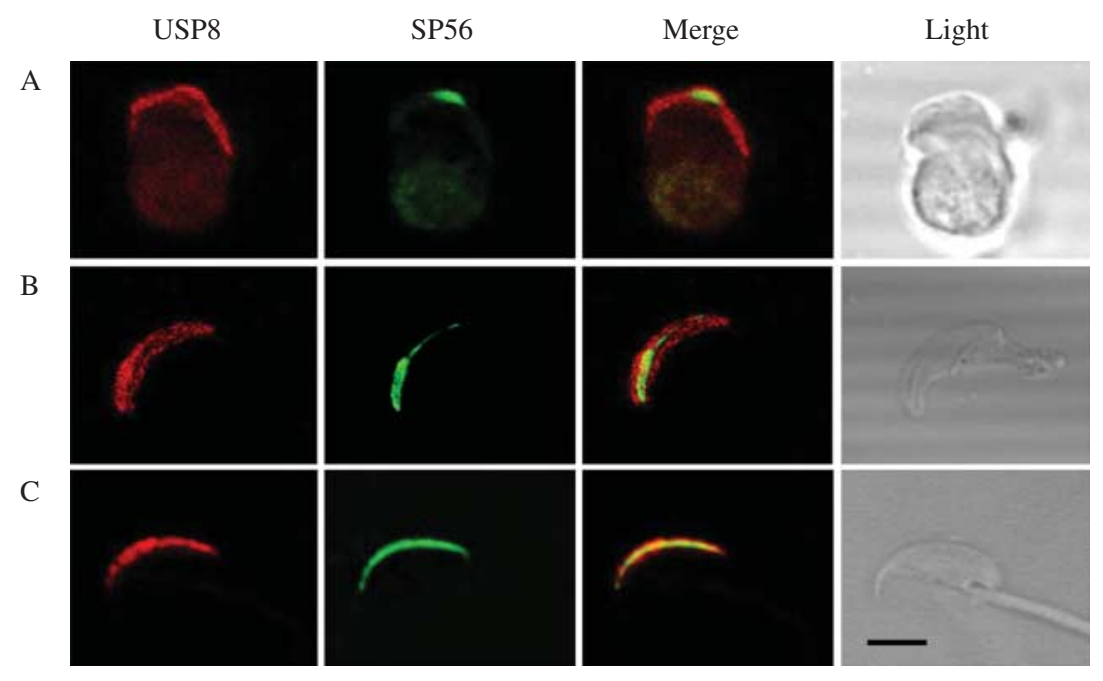

Figure 2 USP8/UBPy and SP56 do not colocalize at late acrosomogenic phases. Spermatids at advanced stages of acrosome biogenesis (A, acrosomal phase; B, maturation phase and C, testis spermatozoon) were immunolabeled against USP8/UBPy and SP56 and examined by confocal microscopy. Yellow signals in the merge of $\mathrm{C}$ can be likely due to the remarkable thinning of the sperm anterior acrosome as highlighted by the light transmission image. Results are representative of at least six cells at each stage in three separate experiments. Bar $=5 \mu \mathrm{m}$. 


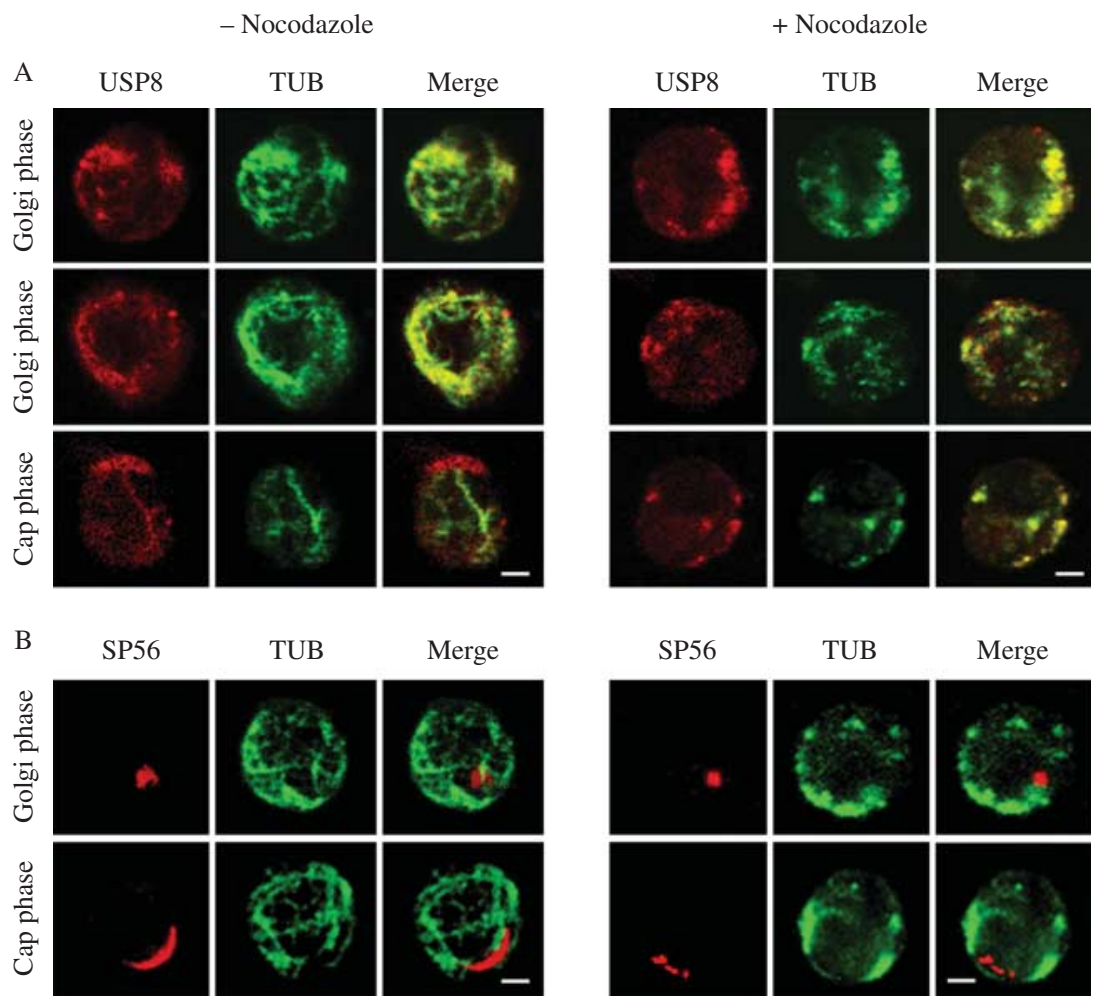

Figure 3 Nocodazole-induced fragmentation of the peripheral microtubule array hampers the trafficking of USP8/UBPy-sorted cargo, but not of SP56, to the developing acrosome. (A) Round spermatids were double immunolabeled against USP8/UBPy and $\beta$-tubulin after nocodazole treatment (right panel) or without nocodazole treatment (left panel). Left panel, $\beta$-tubulin immunostains the cortical microtubule network of untreated Golgiphase spermatids captured at a superficial (top strip) and less superficial (middle strip) section; superimposition of USP8/UBPy and $\beta$-tubulin staining reveals a consistent protein colocalization. The cortical microtubule network dissolves in cap-phase spermatids as shown herein (bottom strip) by $\beta$-tubulin immunolabeling; in cap-phase spermatids, USP8/UBPy marks already the acrosomal cap. Right panel, nocodazole-treated spermatids have the cortical microtubule array, typical of the Golgi phase, fragmented (top and middle strips). Consequently, no USP8/UBPy-stained acrosomal cap could be detected in cap-phase spermatids (bottom strip). (B) Round spermatids at the Golgi and cap phases were double immunolabeled against SP56 and $\beta$-tubulin after nocodazole treatment (right panel) or without nocodazole treatment (left panel). In untreated samples, no significant colocalization between SP56 and the microtubule array was detected. In nocodazole-treated samples, although the cortical network mostly disappeared, SP56 positioned as a proacrosomal granule (Golgi-phase spermatid, at the top) next to the nucleus; in cap-phase, acrosome (at the bottom) shows a discontinuous SP56-labeling. Results are representative images of at least eight cells at each stage per each specific treatment in three independent experiments. Bar $=3.5 \mu \mathrm{m}$.

already labels the cap; neither acrosomal USP8/UBPy (Fig. 3A, left) nor SP56 (Fig. 3B, left) colocalizes with tubulin-marked structures. Taken together, these findings suggest that the cortical network could supply the microtubule tracks along which USP8/UBPy-signed endocytic vesicles are transported to reach the forming acrosome.

To evaluate this hypothesis, we subjected spermatids to nocodazole treatment. At the Golgi phase, nocodazole, a microtubule de-polymerizing drug, induced a fragmentation of the cortical microtubule network; this apparently did not interfere with the association of USP8/UBPy-signed cargo with the fragmented microtubules (Fig. 3A, right). Nocodazole treatment did not affect the positioning of SP56-marked proacrosomal granule toward the nuclear envelope (Fig. 3B, right). The effects of the drug were, however, evident in cap-phase spermatids. The nocodazole-induced disassembling of the cortical array in Golgi-phase spermatids prevented the contribution of USP8/UBPy-sorted protein cargo(es) to the proacrosomal granule; consequently, this last did not evolve into a normal cap (Fig. 3A, compare untreated, left vs nocodazole-treated, right, spermatids). On the other hand, the SP56-signed biosynthetic route (Fig. 3B, right) seemed to be unaffected by the treatment.

\section{MET, USP8/UBPy and their relationship during acrosome biogenesis}

To accomplish with success spermatogenesis, spermatogenic cells have to divide, differentiate and concomitantly migrate within the seminiferous epithelium. MET signaling can regulate cellular proliferation, cellular motogenesis and morphogenesis (Hammond et al. 2001). We thus focused attention on MET, already described as a candidate substrate for USP8/UBPy (Row et al. 2006). Previous immunohistochemical studies reported MET immunopositivity in the embryonic 
(Ricci et al. 1999), postnatal (Catizone et al. 2001) and pre-pubertal (Catizone et al. 1999) testis, however, without any information about MET in post-meiotic spermatids. We analyzed testis from post-pubertal mice at different ages probing two different commercial antimouse MET antibodies directed against the mouse $140 \mathrm{kDa} \beta$-chain and using more immunofluorescence approaches.

Fresh suspensions of spermatogenic cells isolated from testis through enzymatic steps were examined. Independently from the antibody used, MET immunolocalization did not differ consistently; it is summarized in Fig. 4. In spermatocytes (primary and secondary, Fig. 4B and C), MET exhibited mostly a spotted distribution, in particular at the sub-plasmalemmal region. The spot-like distribution apparently increased in round spermatids (Fig. 4D). With the progression of acrosomogenesis, MET was found to label the acrosome (Fig. 4E and F). The acrosome was the only cellular structure to be immunostained in testis spermatozoa (Fig. 4G). MET immunolabeling was also carried out on spermatogenic cells isolated avoiding any enzymatic treatment (Guttman et al. 2004); similar results were, however, obtained (Supplementary Figure 1A, see section on supplementary data given at the end of this article). To possibly preserve cell-cell contacts, we directly immunolabeled fragments of seminiferous tubules squashed onto cover-slips. MET immunopositivity was found at/near the plasma membrane in meiotic cells, whereas post-meiotic cells appeared essentially MET immunonegative (Supplementary Figure 1B). Conversely, with traditional immunohistochemistry, the fluorescence of the crescent-shaped acrosomal vesicle in elongating spermatids dimmed the weaker signal from spermatocytes (Supplementary Figure 1C). Overall, immunofluorescence analysis suggests that MET undergoes a re-routing pathway that delivers it from the cell periphery to the acrosome during the acrosome biogenesis. We thus double-immunostained spermatids, previously subjected to nocodazole treatment, against MET and tubulin. As it is shown in Fig. 5D, the nocodazole-induced disassembling of the cortical microtubule array interferes with the labeling of the acrosomal cap by MET.

The presence of MET was also evaluated by western immunoblotting. The most strong signal was elicited by a band of $\sim 105 \mathrm{kDa}$ from testis homogenate, isolated spermatogenic cells and epididymal spermatozoa; this band, however, was also detected in liver homogenate, used as a positive control (Fig. 5A). Further bands of lower molecular weights (68 and $46 \mathrm{kDa}$, in particular) were occasionally detected, especially when sonication plus Triton X-100 extraction was used (Fig. 5B, left). Parallel blots probed with preadsorbed antibodies were negative, suggesting that the immunodetected molecular bands could be proteolytic products of the canonical 140 kDa $\beta$-chain (Fig. 5A, lower panel, and B, right).

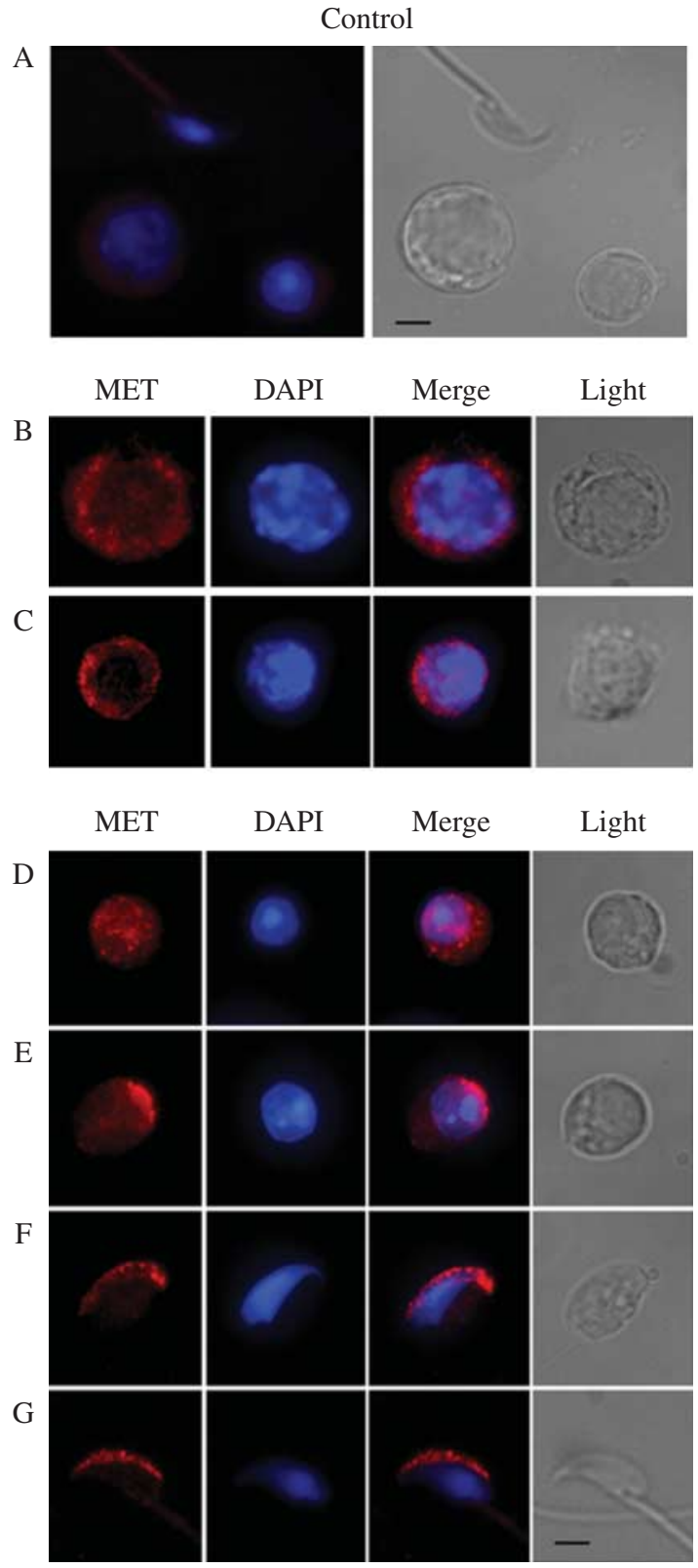

Figure 4 MET redistributes in spermatogenic cells at different stages of cell differentiation. (A) Controls performed with a pre-saturated MET antibody. (B, C, D, E, F and G) Freshly isolated spermatogenic cells immunostained for endogenous MET and counterstained with DAPI. Images were captured under a fluorescence microscope at $63 \times$ magnification. Representative images are provided for primary spermatocytes (B), secondary spermatocytes $(C)$ and spermatids at each acrosomogenic phase (D, E, F and G). Bar $=5 \mu \mathrm{m}$.

Then, we searched for a possible USP8/UBPy-MET association under physiological conditions. We examined this possibility by co-immunoprecipitation experiments. Lysates from freshly isolated spermatogenic cells were precipitated with the USP8/UBPy antibody. Alternatively, spermatogenic cells isolated and cultured in RPMI medium (Aivatiadou et al. 2009) were first HGF stimulated for $30 \mathrm{~min}$ and then lysed in extraction buffer 
A

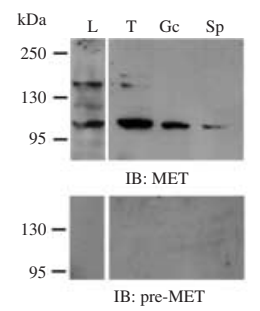

B

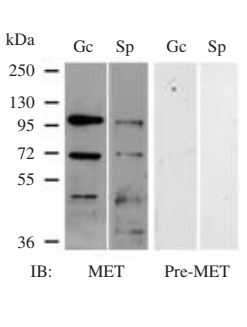

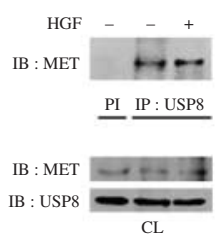

+ Nocodazole

D

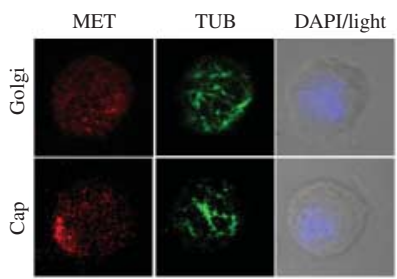

E

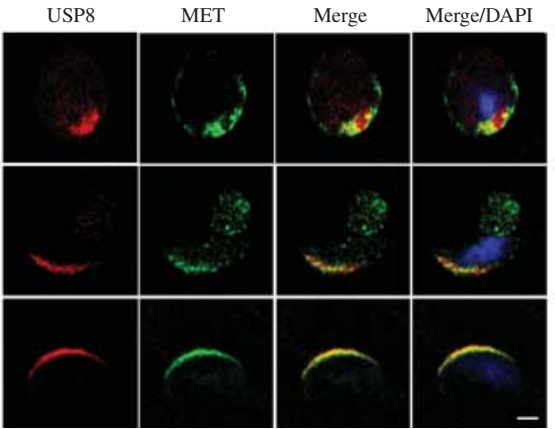

Figure 5 Characterization of MET in male germ cells and its association with USP8/UBPy. (A) Upper panel, liver homogenate (L) used as a positive control, testis homogenate $(\mathrm{T})$ and protein lysates from freshly isolated spermatogenic cells (Gc) and epididymal spermatozoa (Sp) were processed for MET immunoblotting. A $105 \mathrm{kDa}$ immunoreactive band yielded the strongest signal. Lower panel, parallel blot assayed with a pre-saturated MET antibody. (B) Triton X-100 protein extracts from sonicated spermatogenic cells (Gc) and spermatozoa (Sp). More MET immunoreactive bands were revealed (left); a parallel blot probed against a pre-saturated MET antibody (right) did not result in any signal. (C) Protein lysates from unstimulated $(-)$ or cultured spermatogenic cells stimulated with HGF $(+)$ were processed for immunoprecipitation with anti-USP8/UBPy (IP) or preimmune serum (PI). MET interaction was assayed by immunoblotting of the protein precipitates with anti-MET. The two strips below show the blots of the respective cell lysates (CL) probed with anti-MET and anti-USP8/UBPy. (D) Golgiand cap-phase spermatids were double immunolabeled against MET and $\beta$-tubulin after nocodazole treatment ( + nocodazole, right panel) or without nocodazole treatment ( - nocodazole, left panel). Nocodazole-treatment prevents MET labeling of the acrosomal cap. (E) Representative confocal images of spermatids at the cap (upper) and acrosomal phase (middle) and of a cauda epididymal spermatozoon (under) double immunostained against USP8/UBPy (red) and MET (green). Nuclei were counterstained with DAPI. Bar $=4 \mu \mathrm{m}$ in D, $3 \mu \mathrm{m}$ in E. All the experiments shown were performed at least in triplicate.

to be processed as the non-stimulated cells. USP8/UBPy immunoprecipitates, analyzed by SDS-PAGE and blotted, were probed with anti-MET antibodies. It was found that MET co-immunoprecipitates with
USP8/UBPy apparently independently of HGF stimulation (Fig. 5C, upper panel). Finally, we subjected freshly isolated spermatids to double USP8/UBPy-MET immunolabeling. USP8/UBPy-MET colocalization was already detected in cap-phase spermatids and consistently revealed at the acrosome of both elongating spermatids and epididymal spermatozoa (Fig. 5E). Altogether, experimental evidence suggests that USP8/ UBPy could be involved in the re-routing of MET toward the developing acrosome.

\section{USP8/UBPy, MET and the acrosome reaction}

At fertilization, spermatozoa undergo the $A R$, a prerequisite for sperm-egg fusion. During the $A R$, not all the acrosomal proteins are lost; some proteins such as IZUMO (Satouh et al. 2012) and equatorin (Yoshida et al. 2010), known also as MN9 antigen (Toshimori et al. 1992) and/or AFAF (Li et al. 2006), change their localization. The relocation of equatorin and IZUMO from the acrosome to the cell surface is thought to be important for priming sperm molecules for sperm-egg interaction and fusion respectively. We planned to follow the fate of USP8/UBPy and MET at the AR. Cauda epididymal spermatozoa were thus immunolabeled with anti-USP8/UBPy or anti-MET antibodies after artificial induction of the AR (Sosnik et al. 2010) at 0, 5, 15 and $30 \mathrm{~min}$. In parallel, we followed the progression of the AR at each time-point by Coomassie blue staining (Feng et al. 1998). To classify the different patterns of USP8/UBPy and MET localization, we resorted to a nomenclature of AR stages in agreement with Yoshida et al. (2010). At the initial stage (time $0 \mathrm{~min}$ ), when $\sim 88 \%$ of spermatozoa were acrosome intact, USP8/ UBPy (Fig. 6A, left) and MET (Fig. 6A, right) immunostainings were similar to those observed in freshly isolated epididymal spermatozoa (Fig. 5E): the DUB and the receptor marked strongly the dorsal acrosomal cap area of acrosome-intact spermatozoa. We noticed that when the anti-MET SP260, but not the anti-MET B-2, was used, the tail mid-piece of cauda epididymal spermatozoa was also fluorescently labeled. At an early stage (time $5 \mathrm{~min}$ ), USP8/UBPy showed almost the same staining pattern as in the initial stage (Fig. 6A, left), while MET signal resulted already in an apparent change of protein distribution. It was reduced at the OAM, but not at the IAM, of the anterior acrosome exhibiting a rather patchy staining (Fig. 6A, right); moreover, labeling at the marginal sub-acrosomic ring was evidenced. At 15 min of induction of $A R$, more than $40 \%$ spermatozoa were acrosome reacted (ARd). The ARd spermatozoa showed a modified USP8/UBPy labeling: most of USP8/UBPy was lost with the reacted material, while the remnant was restricted selectively to the anterior ventral beak (Fig. 6A, left). On its own, MET exhibited a further translocation to the postacrosomal region/post-acrosomal segment (PAR/PAS) in 
A
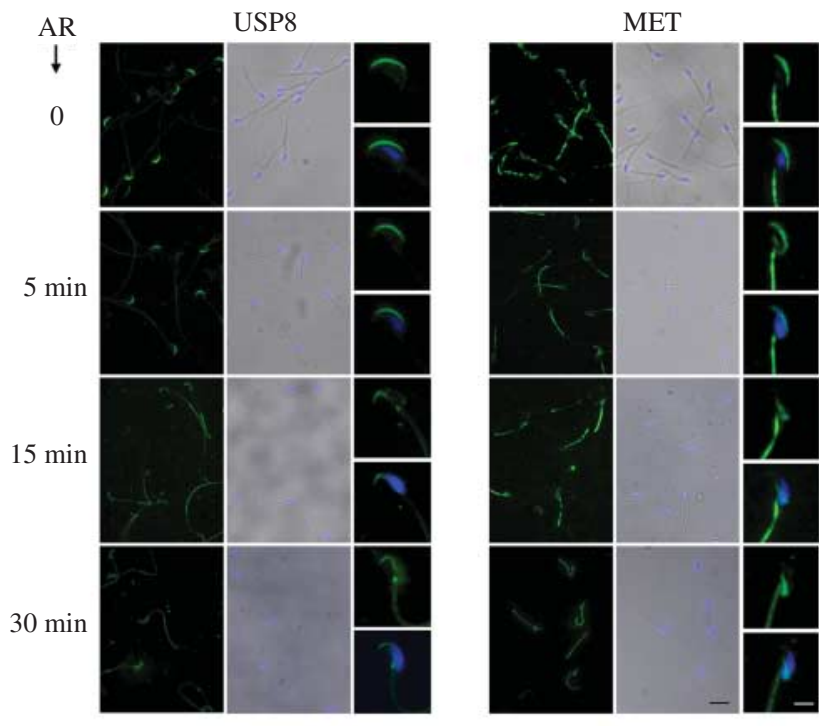

B

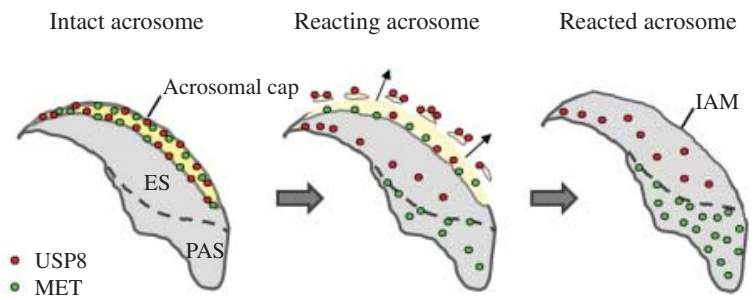

Figure 6 Fate of USP8/UBPy and MET during the acrosome reaction. (A) Cauda epididymal spermatozoa were experimentally induced to react with the acrosome (AR). At the established time interval, a sperm sample was withdrawn and immunostained against either USP8/UBPy (left panel) or MET (right panel) and counterstained with DAPI. At the initial stage (time 0, top strips), both USP8/UBPy and MET hallmark the acrosomal cap. With the progression of the AR, USP8/UBPy and MET stainings differ remarkably. In ARd sperm (bottom strips), the remnant USP8/UBPy, lost mostly with the reacted material, positions at the equatorial segment (ES), whereas MET is migrated to the postacrosomal region (PAS). The fluorescent images at the left side of each strip provide a general view while the images at the middle are the light/DAPI-stained counterparts. The fluorescent images at the right side of each strip are a magnification to allow a better visualization (bar $=6 \mu \mathrm{m}$ ). (B) Schematic drawing showing the estimated protein distribution (USP8/UBPy, red spots and MET, green spots) in acrosomeintact, acrosome-reacting and acrosome-reacted spermatozoa. The localization of USP8/UBPy at the centrosome is not reported.

spermatozoa we considered ARd (Fig. 6A, right); for the others, MET immunostaining was ranged between that described for 5 min-induction and the labeling of the marginal ring (Fig. 6A, right low magnification). At an advanced final stage (time $30 \mathrm{~min} ; \sim 75 \%$ ARd spermatozoa), residual USP8/UBPy labeled the head ventral side including the ventral spur. MET, in turn, located exclusively at the PAR/PAS of ARd sperm (Fig. 6A, right). Based on the changes in the staining pattern according to the progression of $A R$, we schematically summarized the results as illustrated in the drawing of Fig. $6 \mathrm{~B}$.

\section{Discussion}

A former study established that the ESCRT-DUB USP8/UBPy is involved in the acrosome biogenesis and that acrosomes of mature spermatozoa are USP8/UBPy immunopositive (Berruti et al. 2010). This supported the concept of the acrosome as a novel LRO and suggested that the deubiquitinase could be functional also for fertilizing spermatozoa. Herein, we show that USP8/UBPy-regulated endocytic transport concurs with acrosomogenesis already at the early stages and that the disassembling of the microtubule-based transport of USP8/UBPy-signed cargo addressed to the acrosome affects acrosome biogenesis. The identification of the membrane receptor MET as an USP8/ UBPy-sorted cargo recruited to the acrosome and the finding of its relocation after the sperm AR could be results of great potential interest for understanding molecular mechanisms at fertilization.

According to the traditional interpretation of acrosomogenesis, the proacrosomal granule enlarges to become a cap only through the contribution of Golgiderived material. This is believed although it is known that the Golgi pathway is dropping in consequence of its migration toward the opposite pole of the cell (Moreno et al. 2000). Herein, it is shown that the membrane fold-like extensions, typical of the cap phase, of the OAM and IAM are USP8/UBPy positive and SP56 negative. At the previous phase, the Golgi phase, USP8/UBPy stains vesicular structures that are always well distinct from the SP56-positive proacrosomal granules. As no USP8/UBPy-SP56 overlapping was ever revealed at the Golgi as well as cap phase, we can conclude that USP8/UBPy-sorted trafficking and SP56 delivery to the developing acrosome occur via two distinct transport routes. Other proteins resident at the acrosome follow an extra-Golgi pathway. The list includes MN9/equatorin/AFAF (Toshimori et al. 1992, Li et al. 2006, Yoshida et al. 2010), SPE-39 (Zhu et al. 2009) and SMAP2 (Funaki et al. 2013), i.e., proteins that in somatic cells localize to early endosomes and/ or function in early endosome-to-TGN transport. Hence, the acrosome could be effectively thought as an LRO, i.e., a peculiar membranous organelle indispensable for carrying on a cell type-specific physiological function.

As known, the biogenesis of LROs (Huizing et al. 2008, Delevoye et al. 2009) relies on protein vesicular trafficking assisted by microtubule tracks. Herein, we find that, during acrosomogenesis, nocodazole-induced fragmentation of the cortical microtubule array blocks the contribution from the USP8/UBPy-signed endocytic route rather than that derived directly from Golgi. In the presence of nocodazole, in fact, the proacrosomal granule does not evolve into a normal acrosomal cap. Moreno et al. (2006) had already investigated about the effects of nocodazole with the conclusion that the lack of 
assembly of the acrosome in nocodazole-treated spermatids is the consequence of the Golgi fragmentation. In detail, these authors discussed that the drug disorganizes specifically the cortical microtubule array and that this disorganization leads to TGN scattering and TGN separation from the cis-median Golgi. It follows that their observations are in line with our interpretation. Their findings from azh/azh mice also support our conclusion (Moreno et al. 2006). HOOK1, the protein mutated in the azh/azh mouse used as an animal model for detrimental acrosomogenesis, is in fact known to link endocytic, and not biosynthetic, membrane trafficking to the microtubule cytoskeleton (Maldonado-Báez et al. 2013). Moreover, experimental evidence has revealed that other proteins such as AGFG1(HRB)/GOPC, KIFC1 and RAB27A, all suggested to work in the Golgi-to-acrosome pathway in male germ cells (Yang \& Sperry 2003, Kierszenbaum et al. 2011), work indeed at endosomal compartments (Hu et al. 2007, Chaineau et al. 2008).

If the compartment(s) from which specific but undefined cargoes are delivered to the acrosome can be defined, this might aid to identify the cargoes themselves. Thus, we reasoned that if we assume that the acrosome is an LRO and take into consideration that USP8/UBPy governs the trafficking of tyrosine kinase receptors at endosomes, we can succeed in identifying an USP8/UBPy-sorted protein delivered to the acrosome. MET being present in the testis and reported as an USP8/UBPy target receptor, our attention was first devoted to this tyrosine kinase receptor. Thus far, indeed, the knowledge about MET in the testis has been rather confusing with respect to the type(s) of cells that express the receptor (somatic/germ), animal age(s) (embryo/neonatal/prepubertal/adult) and subcellular location(s) (Catizone et al. 1999, 2001, Ricci et al. 1999). Upon the grounds of our immunofluorescence study, we can conclude that the receptor is expressed throughout spermatogenesis exhibiting distinct subcellular localization according to the stage of cell differentiation. In particular, in post-meiotic cells, MET undergoes a drastic change of localization, i.e., from a diffuse scattered distribution in early round spermatids to the acrosome in elongating spermatids/spermatozoa. The most immunoreactive band in immunoblot assays is due to a $105 \mathrm{kDa}$ $\beta$-chain that we confide to correspond to a proteolytic product of the predicted $140 \mathrm{kDa} \beta$-chain. It has to be pointed out, however, that lower molecular weight variants of the MET receptor due to the shedding of extracellular fragments have already been reported (Ancot et al. 2012). Intriguingly, we succeeded to find that MET is able to interact with USP8/UBPy. MET co-immunoprecipitates with USP8/UBPy in freshly isolated as well as cultured, HGF-stimulated, spermatogenic cells. With regard to this, we remember that HGF is produced in testis (van der Wee \& Hofmann 1999), but internalization/trafficking of membrane MET could also occur through ligand-independent pathways of downregulation (Ancot et al. 2012). With further demonstration of MET and USP8/UBPy interaction, there is the protein colocalization in elongating spermatids. Moreover, it is noteworthy that nocodazole was found to prevent MET trafficking toward the developing acrosome. Altogether, experimental evidence is consistent with an USP8/UBPy-regulated sorting of MET toward the forming acrosome.

It follows consequently that not only USP8/UBPy is involved in the biogenesis of a fully formed acrosome, but also the ESCRT-DUB could act as a key regulator of endosomal traffic by directing toward the acrosome molecular players that may be crucial for a successful fertilization. A recent genome-wide association study has identified USP8 as a compelling candidate for male fertility gene (Kosova et al. 2012). The strong USP8/ UBPy-MET colocalization at the acrosome in cauda epididymal spermatozoa was unexpected. The association of 'endocyted receptor/ESCRT DUB' is usually lost when the sorted receptor has reached its final destination. The acrosome may not be the final destination for the MET receptor. Herein, we show that, at the AR, a mandatory step for fertilization, the DUB and the receptor have a different fate. While most of USP8/ UBPy is lost in ARd sperm, MET has translocated massively at the PAS, the posterior head region known to harbor proteins that regulate oocyte activation/early development (Sutovsky et al. 2003). Protein relocation/ translocation is not an unusual event in sperm biology as demonstrated for IZUMO that translocates from the acrosomal membrane to the equatorial segment plasma membrane (Satouh et al. 2012) and MN13 that diffuses from the acrosome to the PAS (Ito et al. 2010). MN13 is one of the numerous candidates to be the sperm factor that triggers oocyte activation (for a review, see ex Amdani et al. (2013)). Currently, however, the most quoted is PLC $\zeta$, the sperm-specific phospholipase $\mathrm{C}$ that generates repetitive $\mathrm{Ca}^{2+}$ transients into the ooplasm of the fertilized oocyte, thus leading to oocyte activation (Saunders et al. 2002). A key, as yet unanswered, question is, however, how the enzyme, inactive within sperm, is activated into the oocyte (Amdani et al. 2013).

It may be hypothesized that MET, once translocated at the PAS surface in ARd sperm, could activate PLC $\zeta$ located at the PAS. In support of this hypothesis, the MET is known to exert its effects through more signaling cascades, including that through the PLCs (Trusolino et al. 2010). PLCs, once tyrosine phosphorylated, increase remarkably their enzymatic activity (Cattaneo et al. 2013). It may be noteworthy to mention that globozoospermic spermatozoa lacking a real acrosome but expressing PLC $\zeta$, as the wobbler mouse spermatozoa (Chianese et al. 2010), fail to fertilize even after intracytoplasmic sperm injection (ICSI) (Heytens et al. 2010).

In conclusion, herein we provide further experimental evidence for the acrosome as an LRO. The identification of sperm MET as an USP8/UBPy-specific target sorted 
to the acrosome and the discovery of its translocation at the AR are original findings that could help to decipher our incomplete understanding of sperm differentiation and fertility potential.

\section{Supplementary data}

This is linked to the online version of the paper at http://dx.doi. org/10.1530/REP-14-0671.

\section{Declaration of interest}

The authors declare that there is no conflict of interest that could be perceived as prejudicing the impartiality of the research reported.

\section{Funding}

This work was financially supported by Italian Ministry of University and Scientific Research (PRIN grant number 2012 to G Berruti).

\section{References}

Aivatiadou E, Ripolone M, Brunetti F \& Berruti G 2009 cAMP-Epac2mediated activation of Rap1 in developing male germ cells: RA-RhoGAP as a possible direct down-stream effector. Molecular Reproduction and Development 76 407-416. (doi:10.1002/mrd.20963)

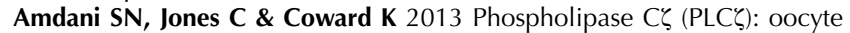
activation and clinical links to male factor infertility. Advances in Biological Regulation 53 292-308. (doi:10.1016/j.jbior.2013.07.005)

Ancot F, Leroy C, Muharram G, Lefebvre J, Vicogne J, Lemiere A, Kherrouche Z, Foveau B, Pourtier A, Melnyk O et al. 2012 Sheddinggenerated Met receptor fragments can be routed to either the proteasomal or the lysosomal degradation pathway. Traffic 13 1261-1272. (doi:10.1111/j.1600-0854.2012.01384.x)

Berruti G \& Martegani E 2005 The deubiquitinating enzyme mUBPy interacts with the sperm-specific molecular chaperone MSJ-1: the relation with the proteasome, acrosome, and centrosome in mouse male germ cells. Biology of Reproduction 72 14-21. (doi:10.1095/ biolreprod.104.030866)

Berruti G \& Martegani E 2013 Ubiquitin specific peptidase 8. In Handbook of Proteolytic Enzymes, 3 edn, pp 2070-2075. Eds ND Rawlings\& GS Salvesen. Oxford: Academic Press.

Berruti G \& Paiardi C 2011 Acrosome biogenesis. Revisiting old questions to yield new insights. Spermatogenesis 195-98. (doi:10.4161/spmg.1.2. 16820)

Berruti G, Ripolone M \& Ceriani M 2010 USP8, a regulator of endosomal sorting, is involved in mouse acrosome biogenesis through interaction with the spermatid ESCRT-0 complex and microtubules. Biology of Reproduction 82 930-939. (doi:10.1095/biolreprod.109.081679)

Birchmeier C, Birchmeier W, Gherardi E \& Vande Woude GF 2003 MET, metastasis, motility and more. Nature Reviews. Molecular Cell Biology 4 915-925. (doi:10.1038/nrm1261)

Catizone A, Ricci G, Arista V, Innocenzi A \& Galdieri M 1999 Hepatocyte growth factor and C-MET are expressed in rat prepubertal testis. Endocrinology 140 3106-3113. (doi:10.1210/endo.140.7.6761)

Catizone A, Ricci G \& Galdieri M 2001 Expression and functional role of hepatocyte growth factor receptor (C-MET) during postnatal rat testis development. Endocrinology 142 1828-1843. (doi:10.1210/endo.142.5. 8172)

Catizone A, Ricci G, Caruso M, Ferranti F, Canipari R \& Galdieri M 2012 Hepatocyte growth factor (HGF) regulates blood-testis barrier (BTB) in adult rats. Molecular and Cellular Endocrinology 348 135-146. (doi:10.1016/j.mce.2011.07.050)
Cattaneo F, Parisi M \& Ammendola R 2013 WKYMVm-induced cross-talk between FPR2 and HGF receptor in human prostate epithelial cell line PNT1A. FEBS Letters 587 1536-1542. (doi:10.1016/j.febslet.2013. 03.036)

Chaineau M, Danglot L, Proux-Gillardeaux V \& Galli T 2008 Role of Hrb in clathrin-dependent endocytosis. Journal of Biological Chemistry 283 34365-34373. (doi:10.1074/jbc.M804587200)

Chianese R, Scarpa D, Berruti G, Cobellis G, Pierantoni R, Fasano S \& Meccariello R 2010 Expression and localization of the deubiquitinating enzyme mUBPy in wobbler mouse testis during spermiogenesis. General and Comparative Endocrinology 166 289-295. (doi:10.1016/j.ygcen. 2009.09.014)

Delevoye C, Hurbain I, Tenza D, Sibarita JB, Uzan-Gafsou S, Ohno H, Geerts WJ, Verkleij AJ, Salamero J, Marks MS et al. 2009 AP-1 and KIF13A coordinate endosomal sorting and positioning during melanosome biogenesis. Journal of Cell Biology 187 247-264. (doi:10.1083/jcb. 200907122)

Feng H, Sandlow JI \& Sandra A 1998 The c-kit receptor and its possible signaling transduction pathway in mouse spermatozoa. Molecular Reproduction and Development 49 317-326. (doi:10.1002/(SICI)10982795(199803)49:3 <317::AID-MRD12>3.0.CO;2-T)

Fujihara Y, Satouh Y, Inoue N, Isotani A, Ikawa M \& Okabe M 2012 SPACA1-deficient male mice are infertile with abnormally shaped sperm heads reminiscent of globozoospermia. Development 139 3583-3589. (doi:10.1242/dev.081778)

Funaki T, Kon S, Tanabe K, Natsume W, Sato S, Shimizu T, Yoshida N, Wong WF, Ogura A, Ogawa T et al. 2013 The Arf GAP SMAP2 is necessary for organized vesicle budding from the trans-Golgi network and subsequent acrosome formation in spermiogenesis. Molecular Biology of the Cell 24 2633-2644. (doi:10.1091/mbc.E13-05-0234)

Gnesutta N, Ceriani M, Innocenti M, Mauri I, Zippel R, Sturani E, Borgonovo B, Berruti G \& Martegani E 2001 Cloning and characterization of mouse UBPy, a deubiquitinating enzyme that interacts with the ras guanine nucleotide exchange factor CDC25(Mm)/Ras-GRF1. Journal of Biological Chemistry 276 39448-39454. (doi:10.1074/jbc. M103454200)

Griffiths G, Ericsson M, Krijnse-Locker J, Nilsson T, Goud B, Söling HD, Tang BL, Wong SH \& Hong W 1994 Localization of the Lys, Asp, Glu, Leu tetrapeptide receptor to the Golgi complex and the intermediate compartment in mammalian cells. Journal of Cell Biology 127 1557-1574. (doi:10.1083/jcb.127.6.1557)

Guttman JA, Takai Y \& Vogl AW 2004 Evidence that tubulobulbar complexes in the seminiferous epithelium are involved with internalization of adhesion junctions. Biology of Reproduction 71 548-559. (doi:10.1095/biolreprod.104.028803)

Guyonnet B, Zabet-Moghaddam M, SanFrancisco S \& Cornwall GA 2012 Isolation and proteomic characterization of the mouse sperm acrosomal matrix. Molecular \& Cellular Proteomics 11 758-774. (doi:10.1074/ mcp.M112.020339)

Hammond DE, Urbé S, Vande Woude GF \& Clague MJ 2001 Downregulation of MET, the receptor for hepatocyte growth factor. Oncogene 20 2761-2770. (doi:10.1038/sj.onc.1204475)

Heytens E, Schmitt-John T, Moser JM, Jensen NM, Soleimani R, Young C, Coward K, Parrington J \& De Sutter P 2010 Reduced fertilization after ICSI and abnormal phospholipase $C \zeta$ presence in spermatozoa from the wobbler mouse. Reproductive Biomedicine Online 21 742-749. (doi:10.1016/j.rbmo.2010.07.006)

Holstein AF, Schirren C \& Schirren CG 1973 Human spermatids and spermatozoa lacking acrosomes. Journal of Reproduction and Fertility 35 489-491. (doi:10.1530/jrf.0.0350489)

Hu ZZ, Valencia JC, Huang H, Chi A, Shabanowitz J, Hearing VJ, Appella E \& Wu C 2007 Comparative bioinformatics analyses and profiling of lysosome-related organelle proteomes. International Journal of Mass Spectrometry 259 147-160. (doi:10.1016/j.ijms.2006.09.024)

Huizing M, Helip-Wooley A, Westbroek W, Gunay-Aygun M \& Gahl WA 2008 Disorders of lysosome-related organelle biogenesis: clinical and molecular genetics. Annual Review of Genomics and Human Genetics 9 359-386. (doi:10.1146/annurev.genom.9.081307.164303)

Ito C, Yamatoya K, Yoshida K, Kyono K, Yao R, Noda T \& Toshimori K 2010 Appearance of an oocyte activation-related substance during spermatogenesis in mice and humans. Human Reproduction 25 2734-2744. (doi:10.1093/humrep/deq216) 
Kierszenbaum AL, Rivkin E \& Tres LL 2011 Cytoskeletal track selection during cargo transport in spermatids is relevant to male fertility. Spermatogenesis 1 221-230. (doi:10.4161/spmg.1.3.18018)

Kim KS, Cha MC \& Gerton GL 2001 Mouse sperm protein sp56 is a component of the acrosomal matrix. Biology of Reproduction 64 36-43. (doi:10.1095/biolreprod64.1.36)

Kosova G, Scott NM, Niederberger C, Prins GS \& Ober C 2012 Genomewide association study identifies candidate genes for male fertility traits in humans. American Journal of Human Genetics 90 950-961. (doi:10.1016/j.ajhg.2012.04.016)

Li YC, Hu XQ, Zhang KY, Guo J, Hu ZY, Tao SX, Xiao LJ, Wang QZ, Han CS \& Liu YX 2006 Afaf, a novel vesicle membrane protein, is related to acrosome formation in murine testis. FEBS Letters 580 4266-4273. (doi:10.1016/j.febslet.2006.06.010)

Lin Y, Roy A, Yan W, Burns KH \& Matzuk MM 2007 Loss of zona pellucida binding proteins in the acrosomal matrix disrupts acrosome biogenesis and sperm morphogenesis. Molecular and Cellular Biology 27 6794-6805. (doi:10.1128/MCB.01029-07)

Maldonado-Báez L, Cole NB, Krämer H \& Donaldson JG 2013 Microtubuledependent endosomal sorting of clathrin-independent cargo by Hook1. Journal of Cell Biology 201 233-247. (doi:10.1083/jcb.201208172)

Mizuno E, Kobayashi K, Yamamoto A, Kitamura N \& Komada M 2006 A deubiquitinating enzyme UBPY regulates the level of protein ubiquitination on endosomes. Traffic 7 1017-1031. (doi:10.1111/j.1600-0854. 2006.00452.x)

Moreno RD, Ramalho-Santos J, Sutovsky P, Chan EK \& Schatten G 2000 Vesicular traffic and Golgi apparatus dynamics during mammalian spermatogenesis: implications for acrosome architecture. Biology of Reproduction 63 89-98. (doi:10.1095/biolreprod63.1.89)

Moreno RD, Palomino J \& Schatten G 2006 Assembly of spermatid acrosome depends on microtubule organization during mammalian spermiogenesis. Developmental Biology 293 218-227. (doi:10.1016/j. ydbio.2006.02.001)

Niendorf S, Oksche A, Kisser A, Lohler J, Prinz M, Schorle H, Feller S, Lewitzky M, Horak I \& Knobeloch KP 2007 Essential role of ubiquitinspecific protease 8 for receptor tyrosine kinase stability and endocytic trafficking in vivo. Molecular and Cellular Biology 27 5029-5039. (doi:10.1128/MCB.01566-06)

Paiardi C, Pasini ME, Gioria M \& Berruti G 2011 Failure of acrosome formation and globozoospermia in the wobbler mouse, a Vps54 spontaneous recessive mutant. Spermatogenesis 1 52-62. (doi:10. 4161/spmg.1.1.14698)

Ricci G \& Catizone A 2014 Pleiotropic activities of HGF/c-Met system in testicular physiology: paracrine and endocrine implications. Frontiers in Endocrinology 5 38. (doi:10.3389/fendo.2014.00038)

Ricci G, Catizone A, Innocenzi A \& Galdieri M 1999 Hepatocyte growth factor (HGF) receptor expression and role of HGF during embryonic mouse testis development. Developmental Biology 216 340-347. (doi:10.1006/dbio.1999.9505)

Row PE, Prior IA, McCullough J, Clague MJ \& Urbé S 2006 The ubiquitin isopeptidase UBPY regulates endosomal ubiquitin dynamics and is essential for receptor downregulation. Journal of Biological Chemistry 281 12618-12624. (doi:10.1074/jbc.M512615200)

Row PE, Liu H, Hayes S, Welchman R, Charalabous P, Hofmann K, Clague MJ, Sanderson CM \& Urbé S 2007 The MIT domain of UBPY constitutes a CHMP binding and endosomal localization signal required for efficient epidermal growth factor receptor degradation. Journal of Biological Chemistry 282 30929-30937. (doi:10.1074/jbc. M704009200)
Satouh Y, Inoue N, Ikawa M \& Okabe M 2012 Visualization of the moment of mouse sperm-egg fusion and dynamic localization of IZUMO1. Journal of Cell Science 125 4985-4990. (doi:10.1242/jcs.100867)

Saunders CM, Larman MG, Parrington J, Cox LJ, Royse J, Blayney LM, Swann K \& Lai FA 2002 PLC 5 : a sperm-specific trigger of $\mathrm{Ca}^{2+}$ oscillations in eggs and embryo development. Development 129 3533-3544.

Sosnik J, Buffone MG \& Visconti PE 2010 Analysis of CAPZA3 localization reveals temporally discrete events during the acrosome reaction. Journal of Cellular Physiology 224 575-580. (doi:10.1002/jcp.22211)

Sutovsky P, Manandhar G, Wu A \& Oko R 2003 Interactions of sperm perinuclear theca with the oocyte: implications for oocyte activation, anti-polyspermy defense, and assisted reproduction. Microscopy Research and Technique 61 362-378. (doi:10.1002/jemt.10350)

Tang XM, Lalli MF \& Clermont Y 1982 A cytochemical study of the Golgi apparatus of the spermatid during spermiogenesis in the rat. American Journal of Anatomy 163 283-294. (doi:10.1002/aja.1001 630402)

Toshimori K, Tanii I, Araki S \& Oura C 1992 Characterization of the antigen recognized by a monoclonal antibody MN9: unique transport pathway to the equatorial segment of sperm head during spermiogenesis. Cell and Tissue Research 270 459-468. (doi:10.1007/BF00645047)

Trusolino L, Bertotti A \& Comoglio PM 2010 MET signalling: principles and functions in development, organ regeneration and cancer. Nature Reviews. Molecular Cell Biology 11 834-848. (doi:10.1038/nrm3012)

van der Wee K \& Hofmann MC 1999 An in vitro tubule assay identifies HGF as a morphogen for the formation of seminiferous tubules in the postnatal mouse testis. Experimental Cell Research 252 175-185. (doi:10.1006/ excr.1999.4630)

Woodard CL, Goodwin CR, Wan J, Xia S, Newman R, Hu J, Zhang J, Hayward SD, Qian J, Laterra J et al. 2013 Profiling the dynamics of a human phosphorylome reveals new components in HGF/C-Met signaling. PLOS ONE 8 e72671. (doi:10.1371/journal.pone.0072671)

Wright MH, Berlin I \& Nash PD 2011 Regulation of endocytic sorting by ESCRT-DUB-mediated deubiquitination. Cell Biochemistry and Biophysics 60 39-46. (doi:10.1007/s12013-011-9181-9)

Yanagimachi R 2011 Mammalian sperm acrosome reaction: where does it begin before fertilization? Biology of Reproduction 85 4-5. (doi:10.1095/ biolreprod.111.092601)

Yang WX \& Sperry AO 2003 C-terminal kinesin motor KIFC1 participates in acrosome biogenesis and vesicle transport. Biology of Reproduction 69 1719-1729. (doi:10.1095/biolreprod.102.014878)

Yoshida K, Ito C, Yamatoya K, Maekawa M, Toyama Y, Suzuki-Toyota F \& Toshimori K 2010 A model of the acrosome reaction progression via the acrosomal membrane-anchored protein equatorin. Reproduction 139 533-544. (doi:10.1530/REP-09-0434)

Zhu GD, Salazar G, Zlatic SA, Fiza B, Doucette MM, Heilman CJ, Levey AI, Faundez V \& L'hernault SW 2009 SPE-39 family proteins interact with the HOPS complex and function in lysosomal delivery. Molecular Biology of the Cell 20 1223-1240. (doi:10.1091/mbc.E08-07-0728)

Received 22 December 2014

First decision 12 February 2015

Revised manuscript received 24 February 2015

Accepted 5 March 2015 